\title{
Morphological and physiological changes in papaya seedlings "Hawaii" irrigated with saline water and application of humic substances
}

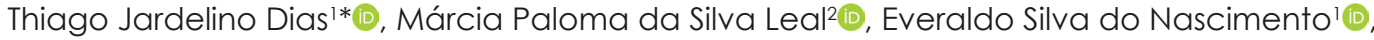 \\ Mário Leno Martins Véras ${ }^{3}$, Toshik larley da Silva ${ }^{4}$, Adriano Salviano Lopes ${ }^{2}$, \\ 'Federal University of Paraiba, Bananeiras, Brazil \\ ${ }^{2}$ Federal University of Paraiba, Areia, Brazil \\ ${ }^{3}$ Federal Institute of Amapá, Macapá, Brazi \\ ${ }^{4}$ Federal University of Viçosa, Viçosa, Brazil \\ *Corresponding author, e-mail: thiagojardelinodias@gmail.com
}

\begin{abstract}
In the northeast semiarid region water with high salt content is very common, which may negatively affect crops growth and development. Thus, using possible salt stress attenuators is extremely important because it allows the use of saline waters for agricultural purposes. Among the possible attenuators of salt stress, humic substances stand out. This work was driven in order to evaluate the effect of the application of humic substances as a possible attenuator of salt stress from papaya seedlings irrigation. The experiment was conducted under entirely randomized design with five replications in a $4 \times 4$ factorial, regarding the four doses of humic substances (5; 10; 15 and $20 \mathrm{~g}$ ), and the electrical conductivity of the irrigation water (ECW 1.5; 3.0; 4.5 and $6 \mathrm{dS} \mathrm{m}^{-1}$ ). Were evaluated: the plant height, stem diameter, leaf number, carbon internal concentration, stomatal conductance, transpiration, net photosynthetic rate, instantaneous water use efficiency and the instantaneous efficiency carboxylation, chlorophyll indices $a, b$, and total ratio of chlorophyll a/chlorophyll b at 70 days of emergence. When it irrigates the papaya seedlings with water of $6.0 \mathrm{dS} \mathrm{m}^{-1}$ is recommended dose of $20 \mathrm{~g}$ of humic substances, which provided greater growth. Irrigation of papaya seedlings with high salinity (3.0 and 4.5 $\mathrm{dS} \mathrm{m}^{-1}$ ) allied with application of $20 \mathrm{~g}$ of humic substances provide increased $\mathrm{CO}_{2}$ concentration, transpiration rate, instantaneous water use efficiency, carboxylation efficiency and chlorophyll b content, however, stomatal conductance, net photosynthesis and chlorophyll a content are reduced with increase of the ECW.
\end{abstract}

Keywords: Carica papaya L., physiology, salt stress, humic acid

\section{Introduction}

Papaya (Carica papaya L.) is a crop of tropical and subtropical climate, adapted to the Brazilian Northeast, it presents great importance in the regional economy, which contributes to social and economic aspects, such as providing employment and income (Diniz et al., 2018; Sá et al., 2013). In the state of Paraíba, seedling production of this species stands out among the fruits, being the 4th largest producer in the northeast (Carvalho, 2017).

However, in this region the water and soil salinity is one of the major obstacles to the production system, therefore increasing the salt concentration in the irrigation water inhibits the germination of seeds, and delay the initial plant growth, thereby it compromises the seedlings formation (Sá et al., 2013; Coelho et al., 2015). The harmful effect of salinity on the initial growth of fruit plants were noted by several authors, as one example, Sá et al. (2013), Mesquita et al. (2014), Mesquita et al. (2015), Santos et al. (2015) and Diniz et al. (2018) in papaya seedlings and in yellow passion fruit plants (Bezerra et al., 2016; Ribeiro et al., 2016).

The adverse effects of salinity on the plants can be mitigated by the use of organic inputs applied to the soil, such as humic substances. These can have direct and indirect effects on plant growth. The indirect effects involve improvements in soil properties, such as aggregation, aeration, permeability, water holding capacity, micronutrients transport and availability. Various studies point that humic substances could present effects against stress, caused mainly by salinity through increasing nutrients absorption and reducing some toxic elements absorption. There are several studies about the application of humic acid and their effect on salinity conditions (Caron et al., 2015).

The benefit of humic substances on saline 
soils is due to the presence of $\mathrm{Ca}, \mathrm{Mg}$ and $\mathrm{K}$ in their composition. The mere presence of these salts could turn other elements more available (Ouni et al., 2014). The mitigating effects of organic inputs occur due to the presence of humic substances in their composition which promote improvements in the soil attributes physical, chemical and biological. Which are reflected in root architecture, the formation of new roots and increased absorption of water and nutrients by plants (Canellas \& Olivares, 2014).

However, there are few studies on the use of attenuators of salt stress in fruit seedlings, especially in papaya seedlings. In this sense, the objective was to evaluate the effect of the application of humic substances as a possible attenuator of salt stress in papaya seedlings "Hawaii" under saline irrigation conditions.

\section{Material and Methods}

The experiment was conducted in greenhouse belonging to the Science Humanities Center, Social and Agricultural - CCHSA of the Federal University of Paraíba UFPB, located in the municipality of Bananeiras-PB, Brazil, located in the geographic coordinates Latitude: -6.75105 Longitude: $35.63346^{\circ} 45^{\prime} 4$ "South, $35^{\circ} 38^{\prime} 0^{\prime \prime}$ West.

The climate by Köppen classification is the type - Tropical rainy, with dry summer. According to the Executive Agency for the Waters Management of the State of Paraíba - AESA, the municipality of BananeirasPB, Brazil, presented during months from January to July 2017, the maximum temperature of 28.4 and 20.2 minimum, while the relative humidity was maximum 93.2 and 92.2 minimum, with cumulative rainfall of $472.7 \mathrm{~mm}$.

Was adopted a completely randomized design with five replications in a factorial $4 \times 4$. The treatments consisted of doses of humic substances $(5,10,15$ and $20 \mathrm{~g})$, and the electrical conductivity of the irrigation water (ECW $1.5 ; 3.0 ; 4.5$ and $6 \mathrm{dS} \mathrm{m}^{-1}$ ). The doses used were based on the work of Cavalcante et al. (2011) and Mesquita et al. (2012) who tested the use of humic substances (humine, fulvic acid and humic acids; Humitec) and biofertilizer chemically enriched in the papaya cultivar 'Formosa' and 'Sunrise Solo', associated with the observations made by Asik et al. (2009) and Canellas \& Olivares, (2014). The experimental units were comprised of three seedlings cultivated in polyethylene pots with a capacity of $5 \mathrm{dm}^{3}$.

Five Papaya seeds of "Hawaii" type were sown directly in the pots at a depth of $1.5 \mathrm{~cm}$ and after 8 days of emergence (DAS) was carried out the thinning, leaving only one seedling per pot. During the experiment, conduction weeding was made as needed.
Pots were filled with soil collected from a depth of $0-20 \mathrm{~cm}$ and classified as oxisol. Soil samples were collected for chemical analysis, which presented the following characteristics (Table 1).

The electrical conductivity of the irrigation water

Table 1. Chemical attributes of the soil used before the experiment.

\begin{tabular}{|c|c|}
\hline Attributes & Values \\
\hline $\mathrm{pH}$ (water $1: 2.5$ ) & 5.20 \\
\hline $\mathrm{Al}^{+3}\left(\mathrm{cmol}_{\mathrm{c}} \mathrm{dm}^{-3}\right)$ & 0.10 \\
\hline $\mathrm{Ca}^{+2}\left(\mathrm{cmol}_{\mathrm{c}} \mathrm{dm}^{-3}\right)$ & 0.50 \\
\hline $\mathrm{Mg}^{2+}\left(\mathrm{cmol}_{\mathrm{c}} \mathrm{dm}^{-3}\right)$ & 0.45 \\
\hline$P\left(\mathrm{mg} . \mathrm{dm}^{-3}\right)$ & 9.82 \\
\hline $\mathrm{K}\left(\mathrm{cmol}_{\mathrm{c}} \mathrm{dm}^{-3}\right)$ & 0.03 \\
\hline $\mathrm{Na}^{+}\left(\mathrm{cmol}_{\mathrm{c}} \mathrm{dm}^{-3}\right)$ & 0.13 \\
\hline $\mathrm{H}^{+}+\mathrm{Al}\left(\mathrm{cmol}_{\mathrm{c}} \mathrm{dm}^{-3}\right)$ & 0.10 \\
\hline O.C. $\left(\mathrm{g} \mathrm{kg}^{-1}\right)$ & 2.35 \\
\hline $\mathrm{SB}\left(\mathrm{cmol}_{\mathrm{c}} \mathrm{dm}^{-3}\right)$ & 1.21 \\
\hline $\operatorname{CEC}\left(\mathrm{cmol}_{\mathrm{c}} \mathrm{dm}^{-3}\right)$ & 1.11 \\
\hline$\vee(\%)$ & 91.7 \\
\hline
\end{tabular}

(ECW) were obtained by adding saline complex ( $\mathrm{NaCl}$ ) to a non-saline water $\left(0.5 \mathrm{dS} \mathrm{m}^{-1}\right)$ from the local supply system, being determined by a digital conductivity meter until the conductivity desired to be reached (ECW 1.5, 3.0, 4.5 and $6.0 \mathrm{dS} \mathrm{m}^{-1}$ ).

The humic substances were obtained from the commercial product and doses were prepared by diluting it to the irrigation water supplied manually and $4 \mathrm{dm}^{3}$ of each mixture to the seedlings being applied 20 days after seedling emergence (DAE) in the interval of 5 in 5 days. The papaya seedlings were irrigated daily, rising at the beginning soil moisture about $80 \%$ of field capacity (Fc), determined by the weighing method and the soil saturation curve.

The source of humic substances was a commercial product Humitec ${ }^{\circledR}$, liquid black coloring soluble in water, containing $16.5 \% \mathrm{p} / \mathrm{v}(15 \% \mathrm{p} / \mathrm{p})$ of the total humic extract, $11.2 \% \mathrm{p} / \mathrm{v}(10 \% \mathrm{p} / \mathrm{p})$ organic carbon, $13.2 \% \mathrm{p} / \mathrm{v}(12 \% \mathrm{p} / \mathrm{p})$ of humic acid, $3.3 \% \mathrm{p} / \mathrm{v}(3 \% \mathrm{p} / \mathrm{p})$ of fulvic acid, $9.0 \% \mathrm{p} / \mathrm{v}$ $(8.0 \mathrm{p} / \mathrm{p})$ of nitrogen soluble in water and $4.5 \% \mathrm{p} / \mathrm{v}(4 \%$ $\mathrm{p} / \mathrm{p})$ of potassium $\left(\mathrm{K}_{2} \mathrm{O}\right)$.

The growth of papaya seedlings was evaluated from the plant height measurements (measurement with a ruler graduated in $\mathrm{cm}$ ), stem diameter (measured using a digital caliper model Starret ${ }^{\circledR} 799$ with with $0.01 \mathrm{~mm}$ accuracy, and the measurement made on the stem base approximately $2 \mathrm{~mm}$ above the ground) and leaf number at 70 days after emergence (DAE).

The effect of different treatments on the physiology of papaya seedlings was evaluated at 70 days after emergence (DAE) by determining the carbon 
internal concentration ( $\mu \mathrm{mol} \mathrm{CO}_{2}$ mol air-1), stomatal conductance $\left(\mathrm{mol} \mathrm{H}_{2} \mathrm{O} \mathrm{m}^{-2} \mathrm{~s}^{-1}\right)$, transpiration (mmol $\left.\mathrm{H}_{2} \mathrm{O} \mathrm{m} \mathrm{m}^{-2} \mathrm{~s}^{-1}\right)$, net photosynthetic rate $\left(\mu \mathrm{mol} \mathrm{CO} \mathrm{CO}^{-2} \mathrm{~s}^{-1}\right)$, instantaneous water use efficiency and the instantaneous efficiency carboxylation using the infrared gas analyzer (IRGA) model LCpro+Sistem with air flow of $300 \mathrm{ml} \mathrm{min}^{-1}$ and the light source $1000 \mu \mathrm{mol} \mathrm{m} \mathrm{m}^{-2} \mathrm{~s}^{-1}$ and chlorophyll indices

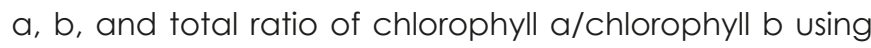
a model chlorophyll meter CFL 1030, which provides measurements of the indeces of chlorophylls $a, b$ and total $(a+b)$, expressed in units of Falker Chlorophyll Index (FCI), during the day (from 8:00 am to 11:00 am), on the third leaf.

The treatment effects were determined by analysis of variance using the F-test, with scrolling the quantitative treatments in polynomial regression components. The choice of model was based on the significance of the coefficients, using the $\mathrm{F}$ test, up to $5 \%$ probability. Statistical analyses were performed using the SAEG software, version 9.1.

\section{Results and Discussion}

There was a significant effect on the interaction between the electrical conductivity in the irrigation water
(ECW) x humic substances for seedling height, leaf number and for stem diameter. Still were recorded interactions to the internal concentration of $\mathrm{CO}_{2}$, carboxylation efficiency and chlorophyll b index, transpiration rate and instantaneous water use efficiency.

For isolated effect, it was observed that the ECW significantly affects the stomatal conductance, net photosynthesis and chlorophyll a being influenced. The application humic substances influenced significantly the stomatal conductance and $\mathrm{CO}_{2}$ internal concentration, respectively. Chlorophyll $a / b$ ratio chlorophyll a/ chlorophyll b and total chlorophyll were not influenced by variation tested factors.

It was observed that papaya seedlings subjected to higher electrical conductivity in the irrigation water with the application of $5 \mathrm{~g}$ of humic substances have restricted the growth in height, with only $8.1 \mathrm{~cm}$ (Figure 1A). However, maintaining the same ECW associated with the application of $20 \mathrm{~g}$ of humic substances, was registered the greatest height in the seedlings, reaching up to $24 \mathrm{~cm}$, that is, comparatively there was a reduction of $15.9 \mathrm{~cm}$ (33.35\% reduction).

Reduction in height of papaya seedlings with
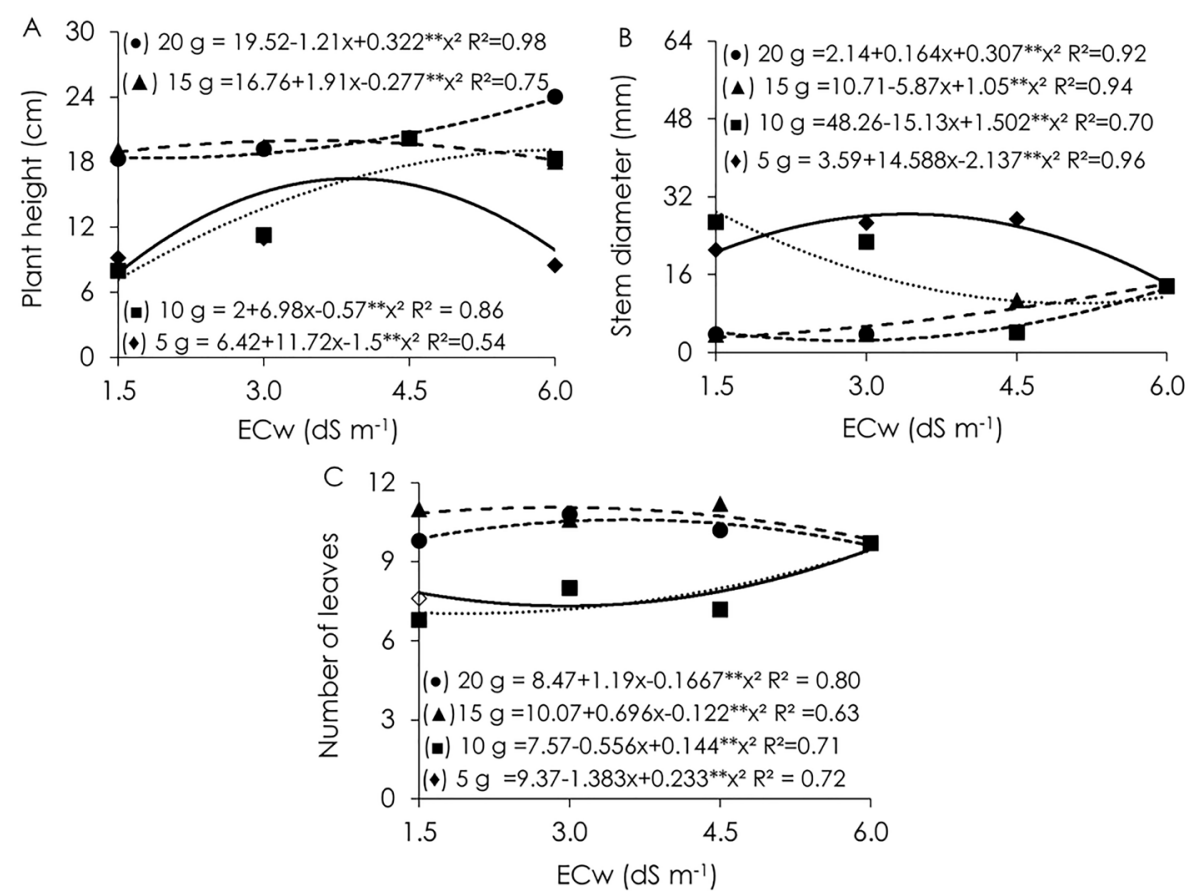

Figure 1. Height (A), stem diameter (B) and number of leaves (C) of papaya seedlings irrigated with saline water and humic substances doses at 70 DAE.

increment of ECW was also observed by Sá et al. (2013) when they found decreases of $29.4 ; 49.2$ and $54.2 \%$ for the electrical conductivities of $2.4 ; 3.6$ and $4.8 \mathrm{dS} \mathrm{m}^{-1}$, in this order, when compared with water $1.2 \mathrm{dS} \mathrm{m}^{-1}$, which did not exceed $15 \mathrm{~cm}$. These results are lower than those obtained in this study, which was obtained $24 \mathrm{~cm}$ in seedling irrigated with water of $6.0 \mathrm{dS}^{-1}$ and application of $20 \mathrm{~g}$ of humic substances (Figure 1A).

Corroborating to these results, Diniz et al. (2018) observed that increasing the ECW have reduced the 
height of papaya seedlings, which had a maximum height of $13 \mathrm{~cm}$ with irrigation water $0.3 \mathrm{dS} \mathrm{m}^{-1}$ and minimum ECW of $4.3 \mathrm{dS} \mathrm{m}^{-1}(8 \mathrm{~cm})$, below those obtained in Figure 1A.

Furthermore, it can be seen from the results presented in Figure 1, that the irrigation water of $6.0 \mathrm{dS} \mathrm{\textrm {m } ^ { - 1 }}$ reduced the height of papaya seedlings even with the application of humic substances, except for using $20 \mathrm{~g}$, in which the seedlings presented $24 \mathrm{~cm}$ of the height that is, increment of $23.75 \%$ in seedling compared to those with the application of $5 \mathrm{~g}$. The greatest height of papaya seedlings with the highest doses of humic substances is due to the larger supply of $\mathrm{Ca}, \mathrm{Mg}$ and $\mathrm{K}$ present. These salts maintain the sites of cation exchange active, aggregating with other elements. To some extent, the $\mathrm{Na}$ becomes more diluted and can be lost by leaching (Ouni et al., 2014).

Similar behavior was observed for the stem diameter, in which the seedlings irrigated with water of $6.0 \mathrm{dS} \mathrm{m} \mathrm{m}^{-1}$ presented $13.68 \mathrm{~mm}$ stem diameter at all doses of humic substances (Figure 1B). However, it was observed that irrigating papaya seedlings with water of $4.5 \mathrm{dS} \mathrm{m}^{-1}$ and with the application of $3.41 \mathrm{~g}$ of humic substances was recorded the largest diameter of the stem $(28.48 \mathrm{~mm})$. Conversely, the smaller stem diameter obtained under ECW of $4.5 \mathrm{dS} \mathrm{m}^{-1}$ and the dose of $15 \mathrm{~g}$ of humic substances, yielding $2.48 \mathrm{~mm}$ at both doses, that is, mean decrease of $84 \%$ compared with the application of $5 \mathrm{~g}$ (Figure 1B).

Diniz et al. (2018) reported that ECW adversely affected stem diameter of papaya seedlings, it was observed reduction until $28.91 \%$ for water up to 4.3 dS $\mathrm{m}^{-1}$ having the largest stem diameter $(6.2 \mathrm{~mm})$ in plants irrigated with water of $1.3 \mathrm{dS} \mathrm{m}^{-1}$, lower than that obtained in the present study, which have stem diameter

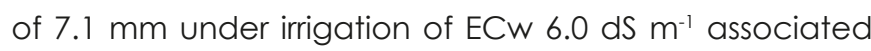
with the application of $20 \mathrm{~g}$ of humic substances. Sá et al. (2013) also found to stem diameter reduction in papaya seedlings of $0.12 \mathrm{~mm}$ in each increase in the ECW, yielding the greatest diameter of $4.5 \mathrm{~mm}$, at 45 DAS under ECW of $1.2 \mathrm{dS} \mathrm{m}^{-1}$, that is, lower than those presented in Figure 1B.

The number of leaves of papaya seedlings, it was found to the most ECW that the dose of $15 \mathrm{~g}$ of humic substances promoted higher values, obtaining 11; 10.6 and 11.2 seedling leaves irrigated with water of 1.5; 3.0 and $4.5 \mathrm{dS} \mathrm{m} \mathrm{m}^{-1}$, respectively, and the smaller numbers of leaves in plants irrigated with measured water at $4.5 \mathrm{dS}$ $\mathrm{m}^{-1}$ with applications of 5 and $10 \mathrm{~g}$ of humic substances, (Figure 1C). These values are superior to those observed by Diniz et al. (2018) with 9.8 leaves in plants irrigated with water of $0.3 \mathrm{dS} \mathrm{m}^{-1}$ and 7.7 leaves with irrigation water

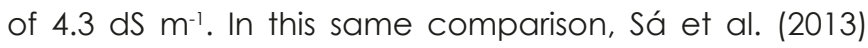
obtained 9 leaves in the seedlings ECW of $1.2 \mathrm{dS} \mathrm{m}^{-1}$ and 5 leaves with irrigation water of $4.8 \mathrm{dS} \mathrm{m}^{-1}$.

It is important to emphasize that in salinity conditions the reduction in plant growth is due to nutritional imbalance by increasing the absorption of $\mathrm{Na}^{+}$ and $\mathrm{Cl}^{-}$and decrease of $\mathrm{K}^{+}$and $\mathrm{Ca}^{2+}$, which are essential for the growth and development of plants (Sá et al, 2013; Coelho et al., 2015).

Thus, the applications of humic substances promote changes in growth, pattern formation and differentiation of plant organs (Canellas \& Olivares, 2014). This stimulating action is attributed, in general, to a direct effect of plant hormones or in hormonal behavior of plants (Boyhan et al., 2001). Particularly the auxin hormone, which can be stimulated in the presence of humic acids, resulting in growth of the plants root system (Baldotto et al., 2017).

It was found that the greater stomatal

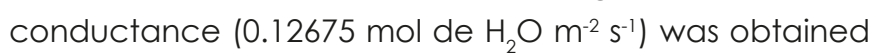
when papaya seedlings were subjected to water with salinity of $1.5 \mathrm{dS} \mathrm{m}^{-1}$, and from this conductivity there was decrease, yielding in the seedlings under higher ECW 16.0 $\mathrm{dS} \mathrm{m}^{-1}$ ) stomatal conductance of $0.065375 \mathrm{~mol} \mathrm{de} \mathrm{H}_{2} \mathrm{O}$ $\mathrm{m}^{-2} \mathrm{~s}^{-1}$, a reduction of $0.061375 \mathrm{~mol}$ de $\mathrm{H}_{2} \mathrm{O} \mathrm{m}^{-2} \mathrm{~s}^{-1}(51.57 \%$ decrease) comparable between seedlings under ECW $6.0 \mathrm{dS} \mathrm{m}^{-1}$ compared to the control (Figure 2A).

Regarding stomatal conductance of papaya seedlings under application of humic substances, was verified dissimilar behavior, that is, the increase in the humic substances doses up to $10 \mathrm{~g}$ provided increase in stomatal conductance. Thus, the seedlings presented the highest value in this dose $0.246792 \mathrm{~mol} \mathrm{de} \mathrm{H}_{2} \mathrm{O} \mathrm{m} \mathrm{m}^{-2}$ $\left.\mathrm{s}^{-1}\right)$ and lower stomatal conductance $(0.178833 \mathrm{~mol}$ de

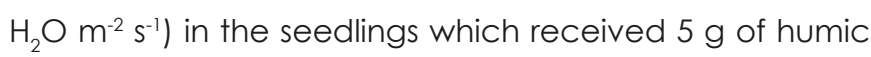
substances, a reduction of $27.53 \%$ (Figure 2B).

The reduction in stomatal of papaya seedlings conductance occurs mainly due to the greater difficulty of seedlings in absorbing water from the soil, and thus, in order to reduce the loss of water, there are stomatal closure, resulting in decreases in important processes for plants, such as net photosynthesis and water use efficiency changes (Oliveira et al., 2017).

The combination of $4.5 \mathrm{dS} \mathrm{m}^{-1}$ and $15 \mathrm{~g}$ of humic substances promoted the highest concentration

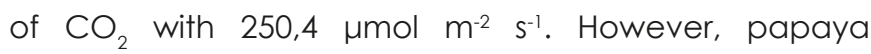
seedlings irrigated with water of $6.0 \mathrm{dS} \mathrm{m}^{-1}$ and doses application of 10 and $20 \mathrm{~g}$ of humic substances had the lowest concentrations of $\mathrm{CO}_{2}$, obtaining 166 and 
$162 \mu \mathrm{mol} \mathrm{m}^{-2} \mathrm{~s}^{-1}$, respectively (Figure $2 \mathrm{C}$ ).

The decrease in internal $\mathrm{CO}_{2}$ concentration in papaya seedlings may have been caused due to the closure of stomata, since the plants close their stomata in order to reduce water loss. Similar behavior was observed by Sá et al. (2018) and Sá et al. (2015) in citrus rootstocks genotypes about saline waters above $0.3 \mathrm{dS} \mathrm{m}^{-1}$ reducing the internal $\mathrm{CO}_{2}$ concentration.

The increase of the salt concentration in the irrigation water and doses of humic substances affected negatively net photosynthesis of papaya seedlings, yielding the net photosynthesis $\left(4.4 \mu \mathrm{mol} \mathrm{CO} \mathrm{CO}^{-2} \mathrm{~s}^{-1}\right)$ in seedlings irrigated with water of $6 \mathrm{dS} \mathrm{m}^{-1}$ and applying $20 \mathrm{~g}$ of humic substance. However, irrigating the papaya seedlings with low salinity $\left(4.5 \mathrm{dS} \mathrm{m}^{-1}\right)$ at a dose of $3.88 \mathrm{~g}$ of humic substances led to the hightest net photosynthesis (17.28 $\mathrm{mol} \mathrm{CO}_{2} \mathrm{~m}^{-2} \mathrm{~s}^{-1}$ ) (Figure 2D).

The transpiration rate of papaya seedlings decreased to $\mathrm{ECW}$ of $4.5 \mathrm{dS} \mathrm{m}^{-1}$, with a raising trend when irrigated with water of $6.0 \mathrm{dS} \mathrm{m}^{-1}$. The higthest transpiration rate was observed in papaya seedlings irrigated with water of $1.52 \mathrm{dS} \mathrm{m}^{-1}$, yielding $10.24 \mathrm{mmol}$ of $\mathrm{H}_{2} \mathrm{O} \mathrm{m} \mathrm{m} \mathrm{s}^{-1}$ and the lowest transpiration rate of 7.27 in the seedlings under $4.94 \mathrm{dS} \mathrm{m}^{-1}$, that is, comparing there is reduction of $31.25 \%$ (Figure 2E).

The decrease in photosynthetic activity may have been caused due to the stomata restrictions, since the highest concentration of $\mathrm{CO}_{2}$ according Campos et al. (2014), occurred in the papaya seedlings under ECW of $4.5 \mathrm{dS} \mathrm{m} \mathrm{m}^{-1}$ (Figure $2 \mathrm{C}$ ), thus it is possible that other factors may have affected the photosynthetic activity, such as inhibiting the activity of rubisco and ATP synthesis (Sabra et al., 2012; Medeiros, 2017). What may have occurred in papaya plants is that if the $\mathrm{CO}_{2}$ internal concentration is below the optimum range the plant uses $\mathrm{CO}_{2}$ respiration for maintaining a minimum level of photosynthetic rate, making it limited (Melo et al., 2017).

Increasing water salinity up to $3.0 \mathrm{dS} \mathrm{m}^{-1}$ and doses
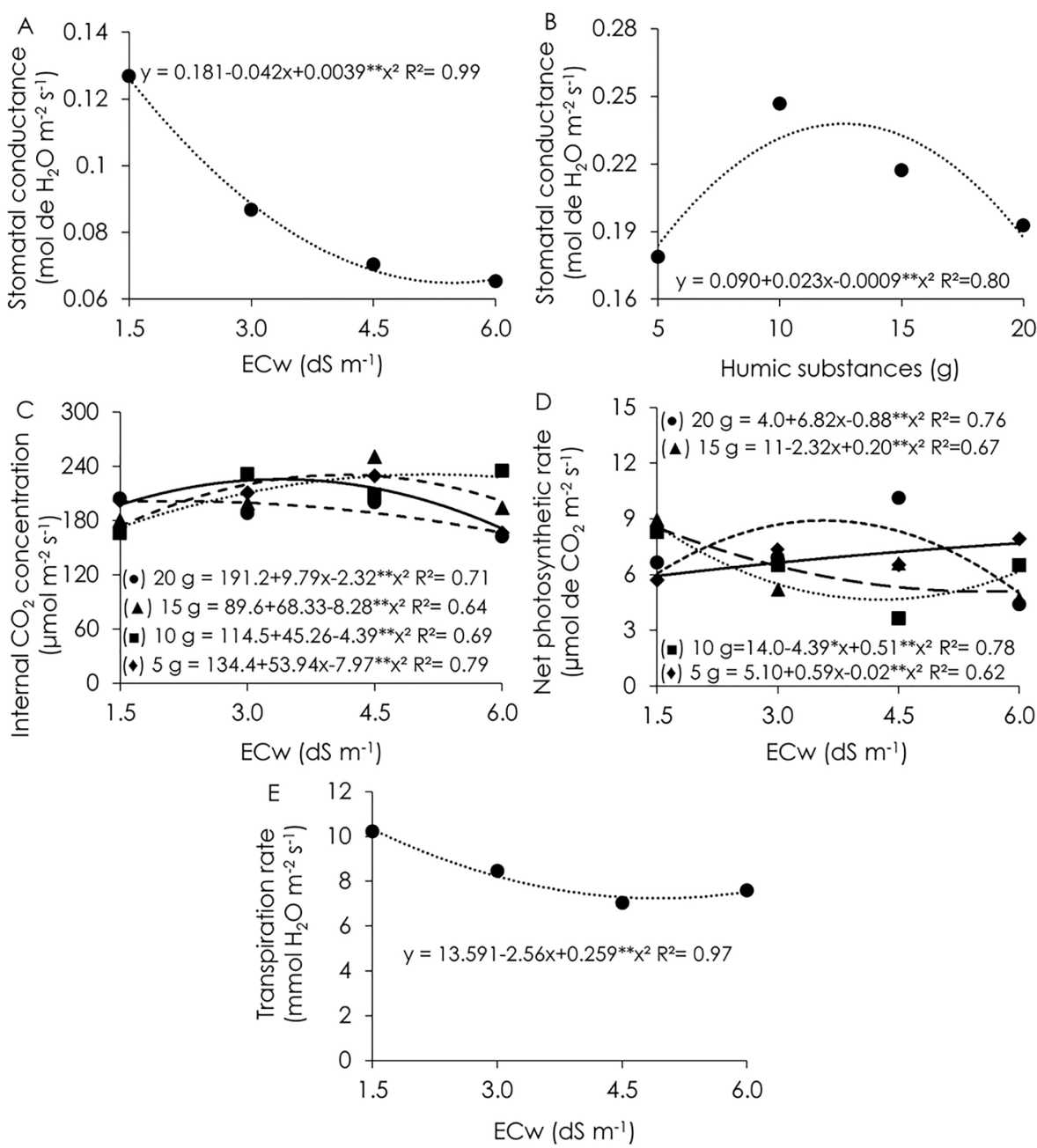

Figure 2. Stomatal conductance (A and B), internal $\mathrm{CO}_{2}$ concentration (C), net photosynthetic rate (D) and transpiration rate (E) of papaya seedlings irrigated with saline water and doses of humic substance at 70 DAE. 
of humic substances promoted instantaneous increase in water use efficiency of papaya seedlings, getting the highest efficiency (5.06) in plants irrigated with water of

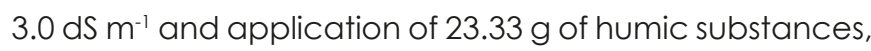
and the lowest instantaneous water use efficiency (2.03) in the managed with ECW of $1.5 \mathrm{dS} \mathrm{m}^{-1}$ and application of $0.04 \mathrm{~g}$ of humic substances (Figure $3 \mathrm{~A}$ ).

The same behavior was observed for the instantaneous efficiency of carboxylation, which was

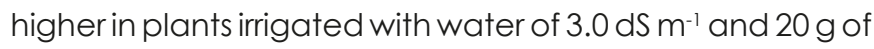
humic substances application, obtaining these treatments 0.1048 instantaneous efficiency of carboxylation. Also was observed that the ECW above $4.5 \mathrm{dS} \mathrm{m}^{-1}$ reduced the instantaneous efficiency of carboxylation (Figure 3B).

The reduction in the efficiency of carboxylation

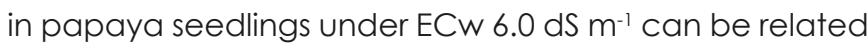
to a decrease in stomatal conductance as related to the internal $\mathrm{CO}_{2}$ concentration, due to osmotic effects of salt stress. However, other cofactors may be involved beyond the stomatal conductance, like chlorophyll a fluorescence (Silva et al., 2014).

In the other hand, the seedlings irrigated with water of $4.5 \mathrm{dS} \mathrm{m}^{-1}$ presented the highest efficiency in water use and efficiency of carboxylation, which may be related to the increased internal concentration of $\mathrm{CO}_{2}$. Although it has presented low internal $\mathrm{CO}_{2}$ concentration, papaya seedlings had a higher instantaneous efficiency of carboxylation, indicating that the ribulose 1.5-bisphosphate carboxylase-/oxygenase (Rubisco) has higher activity (Silva et al. 2014). This may be occurred due to the expression of salt tolerance mechanisms, which may have increased photosynthetic efficiency, favoring the solute flow in the plant and enabling higher dilution and translocation of ions within the plant, consequently, accelerating its compartmentalization in the vacuole (Sá et al., 2015).

It was observed that the chlorophyll a content of the papaya seedlings decreased as the increased salts contents in irrigation water, with higher chlorophyll an index (300.79) with the irrigation water of $1.5 \mathrm{dS} \mathrm{m}^{-1}$; a limitation was being verified about $10.23 \%$ compared to seedlings under ECW of $6.0 \mathrm{dS} \mathrm{m}^{-1}$ (Figure $3 \mathrm{C}$ ). Similar behavior was observed for chlorophyll b content, which decreased as the increase of ECW and humic substances doses, getting 98.14 with irrigation $3.0 \mathrm{dS} \mathrm{m}^{-1}$ and $5 \mathrm{~g}$ of humic substance (Figure 3D).

The decrease in chlorophyll $a$ and b content
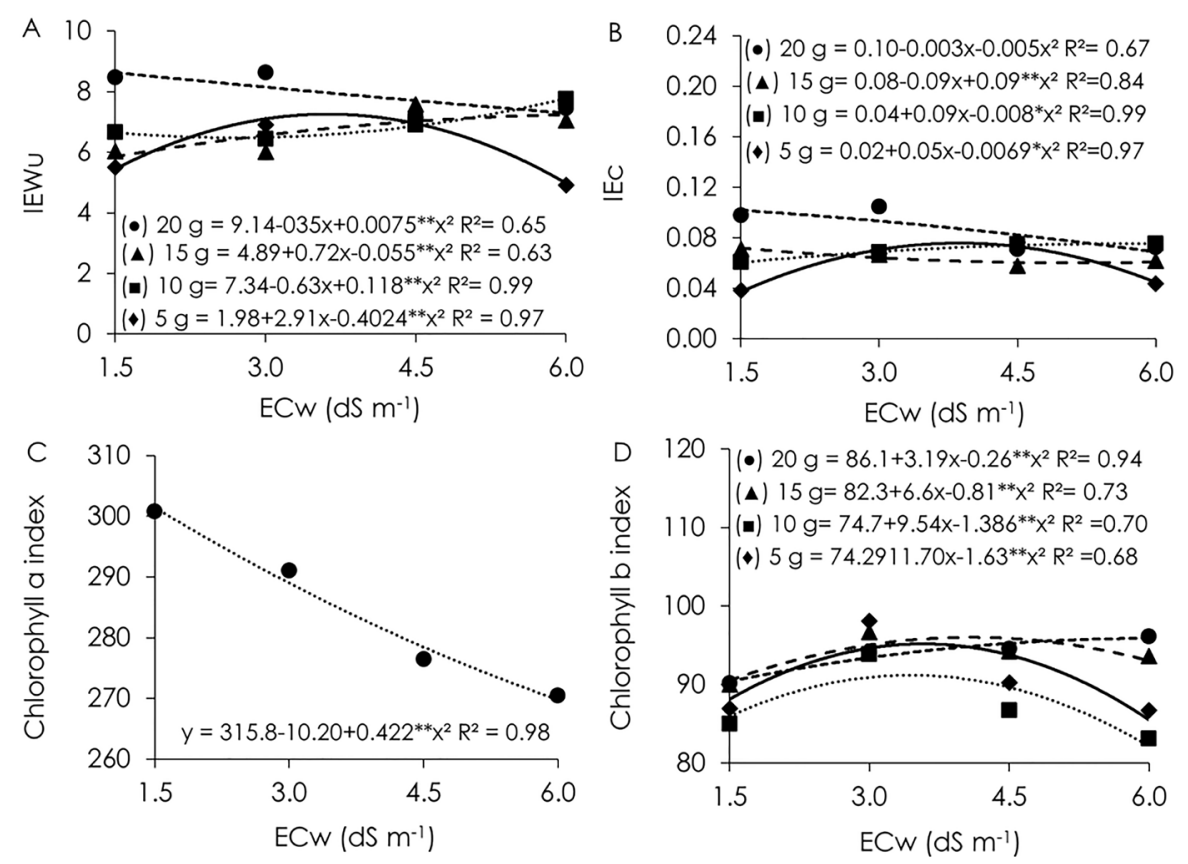

Figure 3. Instantaneous water use efficiency - IEWU - (A), instantaneous efficiency of carboxylation - IEC - (B), chlorophyll an index (C) and chlorophyll b (D) papaya seedlings irrigated with saline water humic substance and dose at 70 DAE.

under conditions of water irrigation with high salinity was also checked by Silva et al. (2014) in citrus when realized that the increase in ECW decreased $31.05 \%$ of the chlorophyll a content reduced $37.86 \%$ in the chlorophyll $\mathrm{b}$, in the seedlings irrigated with saline water in greater concentration in relation to the controls. One of the most remarkable effects of salt stress is the change of the biosynthesis of photosynthetic pigments, since the pigment content of pigments, like chlorophyll, is reduced and as the activity of photosynthetic enzymes also decreases, 
limiting the transport of electrons in chloroplasts, with consequent reduction in the photochemical efficiency of photosystem II (Huang et al., 2012).

According to Ertani et al. (2011) humic substances provide the increase of chlorophyll content also the activity of Rubisco enzyme. The increased chlorophyll content confers to the plant higher light absorption ability, which stimulates the photosynthetic machinery. This was not observed in this study since the higher salinity

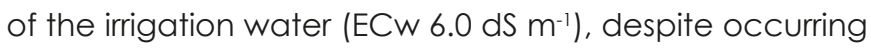
increase levels of chlorophyll $b$, there was a reduction in chlorophyll a content, as well, there was a reduction in net photosynthetic rate (Figure $2 \mathrm{E}$ ), probably due to damage in the photosynthetic apparatus through salts toxicity, especially sodium and chlorine.

In general, the results obtained in growth variables evidenced that the papaya plant is slightly tolerable to salinity associated with humic substances, supporting electrical conductivity of extract of soil saturation between 1.5 to $6 \mathrm{dS} \mathrm{m}^{-1}$ as observed in the present work and also to Lima-Neto et al. (2016). This tolerance is reflected in the plant survivability under stress conditions without inhibition of growth (Figures 1, 2 and 3), higher instantaneous efficiency of water usage (Figure 3A), carboxylation efficiency (Figure 3B) and its productive ability as also demonstrated the benefits of the application of humic substances in mitigation of salt stress.

\section{Conclusions}

When the papaya seedlings are irrigated with water of $6.0 \mathrm{dS} \mathrm{m}^{-1}$, is recommended dose of $20 \mathrm{~g}$ of humic substances, which promoted a higher growth;

Irrigating papaya seedlings with water with salinity from 3.0 to $4.5 \mathrm{dS} \mathrm{m}^{-1}$ combined with application of $20 \mathrm{~g}$ of humic substances provided higher $\mathrm{CO}_{2}$ concentration, transpiration rate, instantaneous water use efficiency, the efficiency of carboxylation and chlorophyll b index, however, stomatal conductance, net photosynthesis and chlorophyll content is reduced with increment of salinity of the irrigation water.

\section{References}

Asik, B.B., Turan, M.A., Celik, H., Katkat, V.A. 2009. Effects of humic substances on plant growth and mineral nutrientes uptake of wheat (Triticum durum cv. Salihli) under conditions of salinity. Asian Journal of Crop Science $1: 87-95$.

Baldotto, M.A., Souza, A.C., Almeida, D.D., Viana, M.C.M., Baldotto, L.E.B. 2017. Bioatividade das substâncias húmicas extraídas de solos manejados com integração, lavoura, pecuária e floresta. Revista Ceres 64: 540-547.
Bezerra, J.D., Pereira, W.E., Silva, J.M., Raposo, R.W.C. 2016. Crescimento de dois genótipos de maracujazeiroamarelo sob condições de salinidade. Revista Ceres 63: 502-508.

Boyhan, G.E., Randle, W.M., Purvis, A.C. 2001. Evaluation of growth stimulants on short-day onions. Hortechnology 11:38-42.

Campos, H., Trejo, C., Peña-Valdivia, C.B., García-Nava, R., Conde-Martínez, F.V., Cruz-Ortega, M.R. 2014. Stomatal and non-stomatal limitations of bell pepper (Capsicum annuum L.) plants under water stress and re-watering: Delayed restoration of photosynthesis during recovery. Environmental and Experimental Botany 98: 56-64.

Canellas, L.P., Olivares F.L. 2014. Physiological responses to humic substances as plant growth promoter. Chemical and Biological Technologies in Agriculture 1: 1-11.

Caron, V.C., Graças, J.P., Castro, P.R.C. 2015. Condicionadores do solo: ácidos húmicos e fúlvicos. ESALQ - Divisão de Biblioteca, Piracicaba, Brazil. 46 p.

Carvalho, C., Kist, B.B., Santos, C.E., Treichel, M., Filter, C. F. 2017. Anuário Brasileiro de Fruticultura. Editora Gazeta, Santa Cruz do Sul, Brazil. 88 p.

Cavalcante, I.H.L., Silva, R.R.S., Albano, F.G., Lima, F.N., Marques, A.S. 2011 . Foliar spray of humic substances on seedling production of Papaya (Pawpaw). Journal of Agronomy 10: 118- 122.

Coelho, D.C., Silva, E.C.B., Silva, F.M., Sousa, E.M.L., Nobre, R.G. 2015. Crescimento de mudas de mamoeiro em condições controladas com água salina. Revista Verde de Agroecologia e Desenvolvimento Sustentável 10: 1-5.

Diniz, G.L., Sales, G.N., Valéria, F.D.O., Andrade, F.H., Silva, S.S., Nobre, R.G. 2018. Produção de mudas de mamoeiro sob salinidade da água irrigação e adubação fosfatada. Revista de Ciências Agrárias 41: 218-228.

Ertani, A., Francioso, O., Tugnoli, V., Righi, V., Nardi, S. 2011. Effect of commercial lignosulfonate-humate on Zea mays L. metabolism. Journal of Agricultural and Food Chemistry 59: $11940-11948$.

Huang, Z., Long, X., Wang, L., Kang, J., Zhang, Z., Zed, R., Liu, Z. 2012. Growth, photosynthesis and $\mathrm{H}^{+}$-ATPase activity in two Jerusalem artichoke varieties under $\mathrm{NaCl}$-induced stress. Process Biochemistry 47: 591-596.

Lima-Neto, A.J., Cavalcante, L.F., Mesquita, F.D.O., Souto, A.G.D.L., Santos, G.P., Santos, J.Z., Mesquita, E.F. 2016. Papaya seedlings irrigation with saline water in soil with bovine biofertilizer. Chilean Journal of Agricultural Research 76: 236-242.

Medeiros, W.J.F., Oliveira, F.Í.F., Lacerda, C.F., Oliveira, D.R., Cruz Oliveira, A. 2017. Efeitos da salinidade do solo e encharcamento sobre as taxas de crescimento de plantas jovens de coqueiro-anão-verde. Revista Brasileira de Agricultura Irrigada 11: 1315-1323.

Melo, H.F.D., Souza, E.R.D., Duarte, H.H., Cunha, J.C., Santos, H.R. 2017. Gas exchange and photosynthetic 
pigments in bell pepper irrigated with saline water. Revista Brasileira de Engenharia Agrícola e Ambiental 21: 38-43.

Mesquita, F.O., Cavalcante, L.F., Pereira, W.E., Rebequi, A.M., Neto, A.J.L., NUNES, J.C. 2012. Produção de mudas de maracujazeiro amarelo submetidas à salinidade em solo como biofertilizante bovino. Ciencia Del Suelo 30: 31-41.

Mesquita, F.O., Batista, R.O., Cavalcante, L.F., Luna Souto, A.G., Lima Neto, A.J., Oliveira, C.J. 2015. Efeito salino da água e da aplicação de biofertilizante sobre o crescimento do mamão Havaí. Magistra 27: 208-216.

Mesquita, F.O., Cavalcante, L.F., Batista, R.O., Medeiros, R.F., Rodrigues, R.M., Oliveira Santos, W. 2014. Avaliação da taxa de crescimento absoluto de mamão Havaí sob o efeito salino e de biofertilizante: Parte I. Magistra 26: 443455.

Oliveira, W.J.D., Souza, E.R.D., Cunha, J.C., Silva, Ê.F.D. F., Veloso, V.D.L. 2017. Leaf gas exchange in cowpea and $\mathrm{CO}_{2}$ efflux in soil irrigated with saline water. Revista Brasileira de Engenharia Agrícola e Ambiental 21: 32-37.

Ouni, Y., Ghnaya, T., Montemurro, F., Abdelly, C., Lakhdar, A. 2014. The role of humic substances in mitigating the harmful effects of soil salinity and improve plant productivity. International Journal of Plant Productivity 8: 353-374.

Ribeiro, A.A., Moreira, F.J.C., Seabra Filho, M., Menezes, A.S. 2016. Emergência do maracujazeiro amarelo sob estresse salino em diferentes substratos. Brazilian Journal of Biosystems Engineering 10: 27-36.

Sá, F.S.V., Brito, M.E.B., Moreira, R.C.L., Andrade Silva, L., Santos Filho, W.S., Figueiredo, L.C., Gheyi, H.R., Fernandes, P.D. 2018. Growth and physiology of citrus rootstocks under salt stress. Bioscience Journal 34: 907-916.

Sá, F.V.D.S., Brito, M.E., Melo, A.D., Antônio Neto, P., Fernandes, P.D., Ferreira, I.B. 2013. Produção de mudas de mamoeiro irrigadas com água salina. Revista Brasileira de Engenharia Agrícola e Ambiental 17: 1047-1054.

Sá, F.V.S., Brito, M.E.B., Andrade Silva, L., Moreira, R.C.L., Fernandes, P.D., Figueiredo, L.C. 2015. Physiology of perception of saline stress in 'Common Sunki' mandarin hybrids under saline hydroponic solution. Comunicata Scientiae 6: 463-470.

Sabra, A., Daayf, F., Renault, S. 2012. Differential physiological and biochemical responses of three Echinacea species to salinity stress. Scientia Horticulturae 135: 23-31.

Santos, D.B., Coelho, E.F., Simões, W.L., Júnior, J.A.S., Coelho Filho, M.A., Batista, R.O. 2015. Influência do balanço de sais sobre o crescimento inicial e aspectos fisiológicos de mamoeiro. Magistra 27: 44-53.

Silva, L.D.A., Brito, M.E., Francisco, V., Moreira, R.C., Soares Filho, W.D.S., Fernandes, P.D. 2014. Mecanismos fisiológicos em híbridos de citros sob estresse salino em cultivo hidropônico. Revista Brasileira de Engenharia Agrícola e Ambiental 18: S1-S7.
Conflict of Interest Statement: The authors declare that the research was conducted in the absence of any commercial or financial relationships that could be construed as a potential conflict of interest.

All the contents of this journal, except where otherwise noted, is licensed under a Creative Commons Attribution License attribuition-type BY. 